University of Rhode Island

DigitalCommons@URI

\title{
HCV Epitope, Homologous to Multiple Human Protein Sequences, Induces a Regulatory T Cell Response in Infected Patients
}

Phyllis T. Losikoff

Sasmita Mishra

Francis Terry

Andres Gutierrez

Matt T. Ardito

Follow this and additional works at: https://digitalcommons.uri.edu/immunology_facpubs

The University of Rhode Island Faculty have made this article openly available.

Please let us know how Open Access to this research benefits you.

This is a pre-publication author manuscript of the final, published article.

Terms of Use

This article is made available under the terms and conditions applicable towards Open Access Policy Articles, as set forth in our Terms of Use.

\section{Citation/Publisher Attribution}

Losikoff, P. T., Mishra, S., Terry, F., Gutierrez, A., Ardito, M. T., Fast, L., Nevola, M., Martin, W. D., BaileyKellogg, C., De Groot, A. S., \& Gregory, S. H. (2014). HCV Epitope, Homologous to Multiple Human Protein Sequences, Induces a Regulatory T Cell Response in Infected Patients. Journal of Hepatology, 62(1), 48-55.

Available at: http://dx.doi.org/10.1016/j.jhep.2014.08.026

This Article is brought to you for free and open access by the Institute for Immunology and Informatics (iCubed) at DigitalCommons@URI. It has been accepted for inclusion in Institute for Immunology and Informatics Faculty Publications by an authorized administrator of DigitalCommons@URI. For more information, please contact digitalcommons-group@uri.edu. 


\section{Authors}

Phyllis T. Losikoff, Sasmita Mishra, Francis Terry, Andres Gutierrez, Matt T. Ardito, Loren Fast, Martha Nevola, William D. Martin, Chris Bailey-Kellogg, Anne S. De Groot, and Stephen H. Gregory 


\section{HCV Epitope, Homologous to Multiple Human Protein Sequences, Induces a Regulatory T Cell Response in Infected Patients.}

ARTICLE in JOURNAL OF HEPATOLOGY · AUGUST 2014

Impact Factor: 11.34 · DOI: 10.1016/j.jhep.2014.08.026 · Source: PubMed

CITATIONS

5

11 AUTHORS, INCLUDING:

Phyllis Losikoff

20 PUBLICATIONS 442 CITATIONS

SEE PROFILE

Martha Nevola

7 PUBLICATIONS 32 CITATIONS

SEE PROFILE

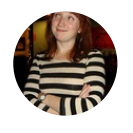

Frances Terry

EpiVax, Inc.

28 PUBLICATIONS 133 CITATIONS

SEE PROFILE

Anne S De Groot

EpiVax, Inc.

213 PUBLICATIONS 3,109 CITATIONS

SEE PROFILE 


\title{
HCV Epitope, Homologous to Multiple Human Protein Sequences, Induces a Regulatory T Cell Response in Infected Patients
}

\author{
Phyllis T. Losikoff, ${ }^{1}$ Sasmita Mishra, ${ }^{1}$ Frances Terry, ${ }^{2}$ Andres Gutierrez, ${ }^{3}$ Matt T. Ardito, ${ }^{2}$ \\ Loren Fast, ${ }^{1,3}$ Martha Nevola, ${ }^{1}$ William D. Martin, ${ }^{2}$ Chris Bailey-Kellogg, ${ }^{4}$ \\ Anne S. De Groot ${ }^{2,3}$ and Stephen H. Gregory ${ }^{1}$ \\ ${ }^{1}$ Department of Medicine, Rhode Island Hospital and the Warren Alpert Medical School of \\ Brown University, Providence, RI; ${ }^{2}$ EpiVax, Inc., Providence, RI; ${ }^{3}$ Institute for Immunology and \\ Informatics, University of Rhode Island, Providence, RI, and ${ }^{4}$ Dartmouth College, Hanover, $\mathrm{NH}$.
}

\section{Tables and 4 Figures; Supplemental Material: 3 Figures, 1 Table}

Abbreviations. $\mathrm{HCV}$, hepatitis $\mathrm{C}$ virus; $\mathrm{T}_{\text {reg }}$ cells, regulatory $\mathrm{T}$ cells; FoxP3, forkhead box P3; $\mathrm{nT}_{\text {reg }}$ cells, natural $\mathrm{T}_{\text {reg }}$ cells; $\mathrm{iT}_{\text {reg }}$ inducible $\mathrm{T}_{\text {reg }}$ cells; BLAST, Basic Local Alignment Search Tool; $\mathrm{T}_{\text {eff }}$ cells, effector T cells; AbVL, antibody/viral load; ICS, immunogenic consensus sequence; TcR, T cell receptor; PBMCs, peripheral blood mononuclear cells; CFSE carboxyfluorescein diacetate, succinimidyl ester.

Disclosures. Anne De Groot and William Martin are senior officers and majority shareholders at EpiVax, Inc. These authors acknowledge a potential conflict of interest and attest that the work contained in this report is free of any bias that might be associated with the commercial goals of the company. None of the remaining authors have conflicts to disclose.

Financial support. Supported by National Institutes of Health Research Grant U19 Al082642.

Corresponding author. Dr. Stephen H. Gregory, Department of Medicine, Rhode Island Hospital and The Warren Alpert Medical School of Brown University, 432 Pierre M. Galletti Building, 55 Claverick Street, Providence, RI 02903. Telephone: 401-444-7369; FAX: 401-444-7524; Email: Stephen Gregory@brown.edu. 


\section{ABSTRACT}

Background \& Aims: Spontaneous resolution of hepatitis C virus (HCV) infections depends upon a broad T cell response to multiple viral epitopes. Most patients fail to clear infections spontaneously, however, and develop chronic disease. The elevated number and function of $\mathrm{CD}^{+} \mathrm{CD}^{+}{ }^{+} \mathrm{CD} 25^{+} \mathrm{FoxP}^{+}$regulatory $\mathrm{T}_{\text {(reg) }}$ cells in $\mathrm{HCV}$-infected patients suggest the role of $\mathrm{T}_{\text {reg }}$ cells in impaired viral clearance. The factors contributing to increased $T_{\text {reg }}$ cell activity in chronic hepatitis $C$ cases remain to be delineated.

Methods: Immunoinformatics tools were used to predict promiscuous, highly-conserved HLA-DRB1restricted immunogenic consensus sequences (ICS), each composed of multiple T cell epitopes. These sequences were synthesized and added to cultures of peripheral blood mononuclear cells (PBMCs) derived from patients who resolved HCV infection spontaneously, patients with persistent infection, and non-infected individuals. The cells were collected following 5 days incubation, quantified and characterized by flow cytometry.

Results: One ICS, HCV_G1_p7_794, induced a marked increase in $T_{\text {reg }}$ cells in PBMC cultures derived from infected patients, but not patients who spontaneously cleared HCV or non-infected individuals. An analogous human peptide (p7_794), on the other hand, induced a significant increase in $\mathrm{T}_{\text {reg }}$ cells among PBMCs derived from both $\mathrm{HCV}$ infected and non-infected individuals. JanusMatrix analyses determined that HCV_G1_p7_794 is comprised of $T_{\text {reg }}$ cell epitopes that exhibit extensive cross-reactivity with the human proteome.

Conclusion: A virus-encoded peptide (HCV_G1_p7_794) with extensive human homology activates cross-reactive $\mathrm{CD}^{+} \mathrm{CD} 4^{+} \mathrm{CD} 25^{+} \mathrm{FoxP}^{+} \quad \mathrm{nT}_{\text {reg }}$ cells, which potentially contribute to immunosuppression and chronic hepatitis C.

Keywords: hepatitis C; regulatory T cells; cross-reactive; epitope 


\section{Introduction}

Chronic hepatitis $\mathrm{C}$ virus $(\mathrm{HCV})$ infection is a major public health concern worldwide. It is the leading cause of liver failure and reason for liver transplant in the US. Irrespective of clinical outcome, acute HCV infections are characterized by broad HCV-specific T cell responses that correlate with spontaneous viral clearance in a minority of individuals [1]. In most patients, however, this initial response fails to contain the virus and chronic disease results. Increased numbers of CD4 ${ }^{+}$regulatory $\mathrm{T}_{(\mathrm{reg})}$ cells circulating in the bloodstream and accumulating in the liver have been implicated in the pathogenesis of chronic hepatitis $C[2,3]$.

$\mathrm{T}_{\text {reg }}$ cells constitute one of the major mechanisms underlying immunological homeostasis and self-tolerance [4]. In addition, $T_{\text {reg }}$ cells play a key role in moderating the immune response to infectious diseases, suppressing host tissue and organ damage that would occur in the absence of regulation [5]. Although key to maintaining immune homeostasis, a growing body of evidence suggests that $T_{\text {reg }}$ cells also contribute to the establishment and persistence of chronic infections, e.g., HCV [6,7]. While no single marker exists, human $T_{\text {reg }}$ cells are classically identified by expression of the transcription factor, forkhead box P3 (FoxP3), and the cell surface expression of the interleukin (IL)-2 receptor a chain (CD25).

Two distinct $T_{\text {reg }}$ cell subsets are described in the literature: natural $(n) T_{\text {reg }}$ cells specific for self epitopes and generated by high-avidity selection in the thymus, and inducible (i) $\mathrm{T}_{\text {reg }}$ cells that derive

from conventional $\left(\mathrm{CD}^{+}{ }^{+} \mathrm{CD} 25^{-}\right.$FoxP3 $\left.{ }^{-}\right) \mathrm{T}$ cells following stimulation in the periphery [8]. $\mathrm{nT}_{\text {reg }}$ cells can induce the conversion of conventional $\mathrm{T}$ cells to $\mathrm{iT}_{\text {reg }}$ cells via cytokine-dependent and -independent mechanisms, a process called infectious tolerance $[9,10]$. Notably, the factors that affect expansion of the $T_{\text {reg }}$ cell population in cases of chronic hepatitis $C$ remain to be fully delineated. Nonetheless, the consensus supports the heterogeneous nature of the expanded $T_{\text {reg }}$ cell population composed of both $n T_{\text {reg }}$ and $\mathrm{iT}_{\text {reg }}$ cell subsets [11]. 
Here, we describe a unique viral peptide derived from HCV p7 protein (HCV_G1_p7_794) that promotes a $T_{\text {reg }}$ cell response among PBMCs derived from patients with persistent HCV infection. This peptide exhibited human homology when evaluated using GenBank Basic Local Alignment Search Tool (BLAST) [12]. Further analysis using a new bioinformatics tool, JanusMatrix [13,14], demonstrated that this HCV peptide cross-reacts with HLA matched peptide sequences located within hundreds of human proteins. Our data suggest that HCV_G1_p7_794 engages preexisting $\mathrm{nT}_{\text {reg }}$ cells as a consequence of this homology, induces infectious tolerance and the expansion of an $i \mathrm{~T}_{\text {reg }}$ cell population, which contributes to suppression of effector $\mathrm{T}_{(\text {eff) }}$ cell activity in cases of chronic HCV infection. 


\section{Materials and Methods}

\section{Subjects}

HCV-seropositive subjects with persistent viremia $\left(\mathrm{Ab}^{+} \mathrm{VL}^{+}\right)$, patients who spontaneously resolved infection $\left(A b^{+} V L^{-}\right)$and $H C V$-seronegative, non-infected $\left(A b^{-} V L^{-}\right)$individuals were recruited from the Rhode Island Adult Corrections Institution to participate in this study. Patients with serological evidence of co-infection with hepatitis B virus or human immunodeficiency virus, reported history of any other immunocompromising condition or prior treatment for HCV were not included. Details of recruitment and the population are described elsewhere [15]. PBMC obtained from subjects were cryopreserved for use in the investigations presented herein. The Institutional Review Boards of the Miriam Hospital, Rhode Island Department of Corrections and Office of Human Research Protection approved this study. All HCV infected subjects were infected with HCV genotype 1a or 1b (Versant HCV genotype assay2, Siemens Healthcare Diagnostics Inc.). Hartford Hospital Transplantation Research Laboratory (Hartford, CT) performed HLA typing. Demographic and serologic data are shown in Table 1.

\section{JanusMatrix analysis}

Crystal structure analyses of ternary, MHC:epitope:T cell receptor (TcR) complexes indicate that certain amino acid residues of a $\mathrm{T}$ cell epitope contact the $\mathrm{MHC}$ molecule while other residues contact the TcR [16]. JanusMatrix, a new bioinformatics tool, interrogates a potential T cell epitope from both its HLA-binding and TcR-facing aspects, and assesses TcR cross-reactivity with $\mathrm{T}$ cell epitopes encoded by other genomes $[13,14]$. Those epitopes from two different genomic sources, e.g., HCV and human, that bind the same HLA molecules and present identical amino acids to the TcR are designated potentially cross-reactive, capable of stimulating the same TcR and triggering the same $\mathrm{T}$ cells to respond. In the analysis undertaken here, JanusMatrix divided the HCV HLA-DRB1restricted epitopes (comprising the ICS described above) into TcR-facing and MHC-binding amino 
acid residues. The human protein database (UniProtKB) was then searched for TcR-facing epitopes that cross-react with the HCV epitopes.

HLA-DRB1-restricted epitope selection, peripheral blood mononuclear cell (PBMC) culture, flow cytometric and statistical analyses.

Detailed descriptions are provided in Supplementary Materials. 


\section{Results}

\section{A peptide sequence in HCV p7 exhibits human homology}

Sustained, virus-specific CD4 and CD8 T cell responses are associated with successful control of $\mathrm{HCV}$ infection. Therapeutic vaccination offers a rational approach to stimulating host resistance and overcoming viral persistence in cases of chronic disease. Toward this end, 20 promiscuous HCV (genotype 1) ICS, each predicted to contain multiple T cell epitopes, were synthesized and validated by demonstrating their ability to bind a panel of the eight common alleles HLA-DRB1 alleles: DRB1 ${ }^{*} 0101,{ }^{*} 0301,{ }^{*} 0401,{ }^{*} 0701,{ }^{*} 0801,{ }^{*} 1101,{ }^{*} 1301$, and ${ }^{*} 1501$, representing essentially the entire human population $[17,18]$. One highly conserved ICS, found in $>90 \%$ genotypes $1 \mathrm{a}$ and $1 \mathrm{~b}$ isolates and located within HCV p7 protein (HCV_G1_p7_794; WPLLLLLLALPQRAYAQ), exhibited significant human homology (>70\% shared identities) determined by GenBank BLAST analysis; none of the remaining ICS exhibited the same homology.

\section{HCV_G1_p7_794 induces a $C D 3^{+} C D 4^{+} F o x P 3^{+} T$ cell response in HCV-infected patients}

A series of experiments was undertaken to determine and compare the HCV_G1_p7_794-specific responses of PBMCs obtained from non-infected control individuals $\left(\mathrm{Ab}^{-} \mathrm{VL}^{-}\right)$, patients who spontaneously cleared $\mathrm{HCV}$ infection $\left(\mathrm{Ab}^{+} \mathrm{VL}\right)$ and infected patients in whom viremia persisted $\left(\mathrm{Ab}^{+} \mathrm{VL}^{+}\right)$. HCV_G1_p7_794 induced a marked increase in $\mathrm{CD}^{+} \mathrm{CD}^{+}$FoxP3 ${ }^{+}$cells when added to PBMC cultures derived from infected, $\mathrm{Ab}^{+} \mathrm{VL}^{+}$patients (Figure 1A). In contrast, HCV_NS4B_1941 (AARVTQILSSLTITQLLKRLHQWI; an ICS that exhibits little human homology) failed to promote a comparable increase. Similarly, other highly conserved HCV ICS with negligible human homology (e.g., HCV_G1_NS4b_1769; ISGIQYLAGLSTLPGNPA) failed to elicit a $\mathrm{CD}^{+} \mathrm{CD}^{+}{ }^{+} \mathrm{FoxP}^{+}$cell response (data not shown). $\mathrm{CD}^{+} \mathrm{CD}^{+} \mathrm{FoxP} 3^{+}$cells, induced by the addition of HCV_G1_p7_794 to $\mathrm{Ab}^{+} \mathrm{VL}^{+}$PBMC cultures, expressed both CD25 (IL-2 receptor a chain, constituently expressed by $\mathrm{T}_{\text {reg }}$ cells) and CD39, a cell ectonucleotidase associated with $\mathrm{T}_{\text {reg }}$ cell function (Figure 1B) $[6,19]$. 
While a significant increase in $\mathrm{CD}^{+} \mathrm{CD} 4^{+} \mathrm{FoxP}^{+}$cells was determined in $\mathrm{PBMC}$ cultures derived from HCV-infected patients, neither HCV_G1_p7_794 nor the control peptide (HCV_G1_NSB4_1941) added to PBMC cultures derived from non-infected individuals or from patients who spontaneously cleared HCV infection induced an increase (Figure $2 \mathrm{~A}$ ). Notably, $\mathrm{Ab}^{+} \mathrm{VL}^{+}$ patients had a higher baseline level of $\mathrm{CD}^{+} \mathrm{CD} 4^{+} \mathrm{Foxp}^{+}$cells compared to clearers or non-infected controls, a finding consistent with the literature [20].

HCV_G1_p7_794 activates cross-reactive $n T_{\text {reg }}$ cells

A human analog of HCV_G1_p7_794 (p7_794, PLLLLLLSLPPRA), identified by GenBank BLAST analysis, was synthesized in an effort to provide a clearer understanding of the nature of the $T_{\text {reg }}$ cells that respond to HCV_G1_p7_794. Like the HCV-encoded homolog, the human analog induced a significant increase in $\mathrm{CD}^{+} \mathrm{CD}^{+}{ }^{+} \mathrm{FoxP}^{+}$cells in $\mathrm{PBMC}$ cultures derived from patients with persistent viremia (Figure 2B). In contrast to HCV_G1_p7_794, however, the human analog also induced an approximate three-fold increase in $\mathrm{CD}^{+} \mathrm{CD}^{+} \mathrm{FoxP}^{+}$cells in $\mathrm{PBMC}$ cultures derived from noninfected ( $\left(A b^{-} V L^{-}\right)$individuals, indicative of the capacity to elicit an $\mathrm{nT}_{\text {reg }}$ cell response.

HCV_G1_p7_794 suppresses the mitogenic response of T cells to anti-CD3 and IL-2 treatment

The hallmark of $\mathrm{CD}^{+} \mathrm{CD}^{+} \mathrm{FoxP}^{+} \mathrm{T}_{\text {reg }}$ cells is suppressor activity. The addition of HCV_G1_p7_794 to $\mathrm{Ab}^{+} \mathrm{VL}^{+} \mathrm{PBMC}$ cultures resulted in a modest, albeit reproducible, decrease in the proliferative response to anti-CD3 monoclonal antibody treatment assessed in terms of a loss in CFSE staining intensity (Figure 3A). Similar results were obtained when $\left[{ }^{3} \mathrm{H}\right]$-thymidine incorporation was used to monitor cell proliferation, i.e., reduced proliferation in response to either anti-CD3 or IL-2 in those cultures that contained HCV_G1_p7_794 (Figure 3B). Importantly, the addition of HCV_G1_p7_794 alone (in the absence of anti-CD3 or IL-2) had no effect on the proliferation of $\mathrm{CD}^{+} \mathrm{CD}^{+} \mathrm{T}$ cells obtained from these same patients. This latter finding indicates that HCV_G1_p7_794 induces the conversion of conventional $\mathrm{CD}^{+} \mathrm{CD} 4^{+} \mathrm{FoxP} 3^{-} \mathrm{T}$ cells to $\mathrm{CD}^{+} \mathrm{CD}^{+} \mathrm{FoxP}^{+} \mathrm{iT}_{\text {reg }}$ cells (i.e., infectious 
tolerance) rather than stimulates the proliferation of $T_{\text {reg }}$ cells already present. An increase in $\mathrm{CD}^{+} \mathrm{CD}^{+}{ }^{+} \mathrm{FoxP}^{+} \mathrm{T}_{\text {reg }}$ cells that lack cell-surface neuropilin-1 supports this suggestion.

CD304 (neuropilin-1) is expressed by a subset of FoxP3 ${ }^{+} \mathrm{T}_{\text {reg }}$ cells in humans [21]. In mice, CD304 expression differentiates natural $\left(C^{2} 304^{+}\right)$, from inducible (CD304 $), T_{\text {reg }}$ cells [22]. While a similar distinction has yet to be reported in humans, it is pertinent to note that the bulk of $\mathrm{CD}^{+} \mathrm{CD}^{+} \mathrm{FoxP}^{+}$cells contained among $\mathrm{Ab}^{+} \mathrm{VL}^{+}$PBMCs cultured in the absence of HCV_G1_p7_794 expressed CD304 indicative of $\mathrm{nT}_{\text {reg }}$ cells (Figure 4A). In contrast, the vast majority of $\mathrm{CD}^{+} \mathrm{CD}^{+}{ }^{+} \mathrm{FoxP} 3^{+}$cells among $\mathrm{Ab}^{+} \mathrm{VL}^{+}$PBMCs cultured in the presence of HCV_G1_p7_794 were CD304 characteristic of $\mathrm{iT}_{\text {reg }}$ cells (Figure 4B). Taken together, these findings support our speculation that HCV_G1_p7_794 recognition by $\mathrm{nT}_{\text {reg }}$ cells following $\mathrm{HCV}$ exposure promotes infectious tolerance and the production of $\mathrm{FoxP}^{+} \mathrm{iT}_{\text {reg }}$ cells from conventional $\mathrm{CD}^{+} \mathrm{CD}^{+} \mathrm{FoxP}^{-} \mathrm{T}$ cells. This contention is supported by experiments demonstrating the failure of HCV_G1_p7_794 to promote an increase in $\mathrm{CD}^{+} \mathrm{CD}^{+}{ }^{+} \mathrm{FoxP} 3^{+}$cells among $\mathrm{Ab}^{+} \mathrm{VL}^{+}$PBMCs depleted of constitutive, CD25-expressing $\left(\mathrm{nT}_{\text {reg }}\right)$ cells prior to culture (Supplementary Figure 1).

JanusMatrix confirms $T_{\text {reg }}$ cell epitopes shared by HCV_G1_p7_974 and the human proteome

By comparing HCV G1_p7_794 with peptide sequences found in the human proteome, JanusMatrix analysis provided further insight into the capacity of HCV_G1_p7_794 to induce a $T_{\text {reg }}$ cell response by PBMCs derived from HCV-infected patients. As illustrated in Table 2, HCV_G1_p7_794 contains five T cell epitopes, which cross-react with 152 putative human T cell epitopes contained in 264 different human proteins. Similarly, the human analog, p7_794, cross-reacts with putative T cell epitopes located within several hundred human proteins. In contrast, neither HCV_G1_NS4b_1941 (control ICS often used in the ex vivo experiments described above) nor any of the 18 other putative ICS, validated by their ability to elicit immune recognition and IFN-Y production by naïve human T cells ex vivo [17], exhibited significant cross-reactivity with the human proteome. Moreover, HCV_G1_p7_794 induced substantially fewer naïve T cells to produce IFN-y assessed by ELISpot 
assay, i.e., $64+75$ versus $655+591$ (mean \pm SD number of spots $/ 10^{6} T$ cells, $n=8$ ) for HCV_G1_p7_794 and HCV_G1_NS4b, respectively; values are significantly different $(p=0.021$; Mann-Whitney rank sum test). The relative inability to induce IFN-Y production supports our speculation that, rather than activate $\mathrm{T}_{\text {eff }}$ cells, HCV_G1_p7_794 activates a cross-reactive $\mathrm{nT}_{\text {reg }}$ cell population that normally functions to suppress autoimmune responses to a large number of human proteins, which contain a common peptide sequence (epitope). 


\section{Discussion}

Resolution of primary HCV infections is dependent upon the vigorous response of $\mathrm{CD} 4^{+}$and $\mathrm{CD} 8^{+} \mathrm{T}$ cells to multiple viral epitopes [23]. HCV persists in the majority of infected patients, however, by modifying and/or evading the host immune response. Purportedly, a variety of factors contribute to the diminished T cell responses observed in chronically infected patients including: viral mutation and escape linked to both CD4 and CD8 T cell failure, CD4 T cell anergy, CD8 T cell exhaustion, impaired dendritic cell function, and $T_{\text {reg }}$ cell-mediated suppression $[2,3,6,7,24,25]$. The increased frequency of $T_{\text {reg }}$ cells found in the liver and circulating in the peripheral blood of chronically-infected patients, confirmed in the current study (Figure 2), provided an initial indication of the role of $T_{\text {reg }}$ cells in the pathogenesis of chronic hepatitis $C$ [2,3,5,11]. It remained unclear until recently, however, whether this increase represented the HCV epitope-specific response of $\mathrm{T}_{\text {reg }}$ cells or the nonspecific consequence of chronic inflammation and liver disease [7].

The ability of HCV-derived epitopes to stimulate $T_{\text {reg }}$ cell responses is well documented; epitopes associated with both structural and non-structural HCV proteins have been reported $[20,26]$. Using HLA class II-peptide tetramer complexes, other investigators quantified and characterized the response of $T_{\text {reg }}$ cell specific for single HCV epitopes $[20,26]$. The study described herein is the first, however, to identify a promiscuous HCV peptide sequence (HCV_G1_p7_794) that exhibits extensive human homology and the ability to elicit a $T_{\text {reg }}$ cell response in a wide, HLA-diverse human population, such as the infected patient population shown in Table I. Unlike the $T_{\text {reg }}$ cell epitopes described previously, HCV_G1_p7_794 is an ICS composed of multiple HLA binding motifs able to bind a number of DRB1 alleles. Unfortunately, this precludes construction of an HLA-peptide tetramer complex and quantitation of the HCV_G1_p7_794-responsive cells. In accord with the literature, HCV_G1_p7_794 added to PBMCs cultures derived from HCV-infected patients, but not non-infected individuals or patients who cleared infection, induced a marked increase in $\mathrm{CD}^{+} \mathrm{CD} 4^{+} \mathrm{FoxP} 3^{+}$cells $[20,26]$. In addition to expressing CD25, characteristic of $T_{\text {reg }}$ cells, the vast majority of these cells 
expressed CD39, a marker that distinguishes FoxP3 ${ }^{+} \mathrm{T}_{\text {reg }}$ cells from activated $\mathrm{T}_{\text {eff }}$ cells that transiently express FoxP3 [6,19].

In contrast to HCV_G1_p7_794, the human peptide analog (p7_794) elicited a significant increase in $\mathrm{CD}^{+} \mathrm{CD}^{+}{ }^{+} \mathrm{FoxP}^{+}$cells in PBMC cultures derived from non-infected individuals with no evidence of prior HCV exposure, as well as HCV-infected patients. This finding is congruent with the suggestion that viral epitopes with human homology influence the pathogenesis of chronic HCV by activating preexisting, cross-reactive $\mathrm{nT}_{\text {reg }}$ cells [11]. Indeed, extensive homology between the HCV polyprotein and proteins that comprise human proteome is well documented [27,28]. JanusMatrix, a bioinformatics algorithm that interrogates potential T cell epitopes from both their HLA-binding and TcR-facing aspects, confirmed the existence of significant homology between HCV_G1_p7_794 and proteins that compose the human proteome. The results of this analysis demonstrate the potential efficacy of JanusMatrix in identifying pathogen-encoded epitopes that elicit the activity of $\mathrm{nT}_{\text {reg }}$ cells, which normally function to suppress autoimmune reactivity to self-antigens (proteins). In this regard, it is pertinent to remark that HCV_G1_p7_794 is comprised of epitopes that are homologous to those found in hundreds of human proteins. This suggests the autoimmune response to a large number of proteins is inhibited by a single or limited number of $\mathrm{nT}_{\text {reg }}$ cell clones responsive to a common peptide sequence, rather than a large number of clones each responsive to a unique sequence in a single protein only. The oligoclonality of the $T_{\text {reg }}$ cell response to HCV_G1_p7_794 and its human analog is a matter of ongoing investigation.

The majority of individuals in our patient population were infected with HCV genotype 1, the derivation of HCV_G1_p7_794. The addition of HCV_G1_p7_794 to PBMC cultures derived from a single HCV genotype 3-infected patient, however, also resulted in a marked increase in $\mathrm{CD}^{+} \mathrm{CD} 4^{+} \mathrm{FoxP}^{+} \mathrm{CD} 25^{+}$cells (Supplementary Figure 2). It is pertinent to note, in this regard, that HCV genotype 3 encodes a peptide sequence: LALLVLLLPQRAYAW, which exhibits HCV_G1_p7_794 homology. 
Conceivably, other viral pathogens that cause chronic disease, e.g., herpes simplex, EpsteinBarr, human immunodeficiency and cytomegalovirus, also avoid or reduce $T_{\text {eff }}$ cell responses by exploiting similarity to self and activating $\mathrm{nT}_{\text {reg }}$ cells $[29,30]$. Indeed, recent analyses indicated that Epstein-Barr virus and cytomegalovirus contained fewer T cell epitopes and exhibited higher crossreactivity with the human genome than did either Ebola or Marburg virus [14]. Ebola and Marburg viruses, on the other hand, were composed of significantly fewer peptide sequences that were crossreactive with human and expressed a larger number of predicted $T$ cell epitopes. Thus, viruses that cause acute disease and viruses such as HCV, which adapt to humans and cause chronic infection, may differ substantially in terms of their $\mathrm{T}_{\text {reg }}$ cell epitope content.

Although immunosuppression by $T_{\text {reg }}$ cells is readily demonstrated in mice, demonstrating the suppressor activity of human $\mathrm{CD} 3^{+} \mathrm{CD} 4^{+} \mathrm{CD} 25^{+} \mathrm{FoxP}^{+} \mathrm{T}_{\text {reg }}$ cells has proven problematic [31]. Recent studies indicate that the nature of the responder $\mathrm{T}$ cells $\left(\mathrm{CD} 4^{+} \mathrm{CD} 25^{-}\right.$versus $\left.\mathrm{CD} 4^{+} \mathrm{CD} 25^{\text {low }}\right)$ and the ratio of $T_{\text {reg }}$ cells to responder cells exert significant effects on the outcome of suppression assays [32,33]. Nonetheless, the HCV_G1_p7_794 responsive $T_{\text {reg }}$ cells suppressed the mitogenic response of cells derived from HCV infected patient in the experiments reported here despite the fact that the $\mathrm{CD}^{+} \mathrm{CD} 4^{+} \mathrm{FoxP} 3^{-}$responder cells far outnumbered $\mathrm{CD} 3^{+} \mathrm{CD} 4^{+} \mathrm{CD} 25^{+} \mathrm{FoxP} 3^{+}$suppressor cells among total PBMCs by a greater than 10:1 ratio,

Notably, the addition of HCV_G1_p7_794 alone to PBMC cultures derived from HCV-infected $\left(\mathrm{Ab}^{+} \mathrm{VL} \mathrm{L}^{+}\right)$patients failed to induce cell proliferation despite a marked (3- to 4-fold) increase in $\mathrm{CD}^{+} \mathrm{CD} 4^{+} \mathrm{CD} 25^{+} \mathrm{FoxP}^{+}$cell number. This finding indicates that HCV_G1_p7_794 induces the conversion of conventional $\mathrm{CD}^{+} \mathrm{FoxP}^{-} \mathrm{T}$ cells to $\mathrm{T}_{\text {reg }}$ cells, i.e., infectious tolerance, a suggestion supported by studies demonstrating the inability of $\mathrm{nT}_{\text {reg }}$ cells to proliferate in response to their cognate antigen in vitro [34]. Furthermore, in contrast to $\mathrm{Ab}^{+} \mathrm{VL}^{+} \mathrm{PBMCs}$ cultured in medium alone, only a minority of $\mathrm{CD}^{+} \mathrm{CD}^{+}{ }^{+} \mathrm{FoxP} 3^{+}$cells cultured in the presence of HCV_G1_p7_794 expressed CD304 (neuropilin), which is expressed by a subset of FoxP3 ${ }^{+} \mathrm{T}_{\text {reg }}$ cells in humans and associated specifically with $\mathrm{nT}_{\text {reg }}$ cells in mice $[21,22]$. While it has been suggested alternatively that the 
expanded $T_{\text {reg }}$ cell population in chronic, HCV infected patients is composed of cells phenotypically similar to $n T_{\text {reg }}$ or $i T_{\text {reg }}$ cells $[11,20]$, our results concur with the consensus that the expanded $T_{\text {reg }}$ cell population in chronic HCV-infected patients is heterogeneous, composed of both $\mathrm{T}_{\text {reg }}$ cell subsets.

HCV p7, a 63-amino acid polypeptide chain that spans the endoplasmic reticulum membrane of infected cells, is essential for viral replication [35]. Hydrophobicity is a common characteristic of hepatitis C viral epitopes [36]. As such, the hydrophobic nature of HCV_G1_p7_794 is unlikely to account for the disparate responses of $\mathrm{CD}^{+} \mathrm{CD} 4^{+} \mathrm{FoxP}^{+} \mathrm{T}_{\text {reg }}$ cells in infected and non-infected individuals. Moreover, while glycosylation can impair T cell recognition [36], there is no evidence to suggest that HCV p7 is glycosylated or that glycosylation affects the differential response to HCV_G1_p7_794. Indeed, the same non-glycosylated synthetic peptide (HCV_G1_p7_794) added to cultures of infected and non-infected PBMCs elicited different outcomes. Rather, the findings reported herein suggest that HCV_G1_p7_794 is a unique peptide sequence recognized by $\mathrm{nT}_{\text {reg }}$ cells that function normally to suppress the autoimmune response to hundreds of human proteins that contain the p7_794 sequence. Upon HCV_G1_p7_794 recognition, these $\mathrm{nT}_{\text {reg }}$ cells induce the conversion of conventional $\mathrm{T}$ cells to $\mathrm{iT}_{\text {reg }}$ cells (i.e. infectious tolerance). We speculate that the $\mathrm{nT}_{\text {reg }}$ cells and $\mathrm{iT}_{\text {reg }}$ cells responsive to HCV_G1_p7_794 contribute to the elevated $T_{\text {reg }}$ cell population found in HCVinfected patients, and play a role in immunosuppression and viral persistence.

The mechanism(s) that underlies the elevated $T_{\text {reg }}$ cell response to HCV_G1_p7_794 observed in HCV-infected, but not non-infected, individuals remains to be determined. We hypothesize, however, that dysfunctional interaction with antigen-presenting cells is involved. Most studies indicate that DCs are functionally impaired in patients with chronic hepatitis $C[6,37]$. Impairments include: decreased IFN- $\alpha$ and IL-12 secretion, lowered expression of co-stimulatory molecules (CD80 and CD86) and an increased ability to prime $T_{\text {reg }}$ cells. In addition, a recent report suggests that $B$ cells contribute to the increase in $T_{\text {reg }}$ cells associated with chronic hepatitis $C$ [38]. Indeed, naïve pan $T$ cells co-cultured with purified $\mathrm{CD}_{19}{ }^{+} \mathrm{B}$ cells in the presence of HCV_G1_p7_794, but not HCV_G1_NS4b_1941 or medium alone, exhibited a marked (3-4-fold) increase in $\mathrm{CD}^{+} \mathrm{CD}^{+} \mathrm{FoxP}^{+}$ 
cells (Supplementary Table I). Notably, the HCV_G1_p7_794 responsive cells were phenotypically consistent with $\mathrm{iT}_{\text {reg }}$ cells expressing neither CD304 nor Helios, markers associated with $\mathrm{nT}_{\text {reg }}$ cells $[21,22,39]$. The potential contribution of APCs to the disparate T cell responses to HCV_G1_p7_794 observed in HCV-infected and non-infected individuals is illustrated in the schematic shown in Supplementary Figure 3. The ex vivo systems described herein enable detailed analyses of the mechanisms that underlie the generation and function of these HCV_G1_p7_794 responsive cells. 


\section{Acknowledgment}

We are grateful to Joseph Desrosiers (URI) for conducting the flow cytometric analyses shown. 


\section{References}

[1] Schulze zur WJ, Ciuffreda D, Lewis-Ximenez L, Kasprowicz V, Nolan BE, Streeck H, et al. Broadly directed virus-specific $\mathrm{CD}^{+} \mathrm{T}$ cell responses are primed during acute hepatitis $\mathrm{C}$ infection, but rapidly disappear from human blood with viral persistence. J Exp Med 2012; 209: 61-75.

[2] Cabrera R, Tu Z, Xu Y, Firpi RJ, Rosen HR, Liu C, et al. An immunomodulatory role for $\mathrm{CD}^{+} \mathrm{CD}^{2} 5^{+}$regulatory $\mathrm{T}$ lymphocytes in hepatitis C virus infection. Hepatology 2004; 40: 1062-71.

[3] Ward SM, Fox BC, Brown PJ, Worthington J, Fox SB, Chapman RW, et al. Quantification and localisation of $\mathrm{FOXP3}^{+} \mathrm{T}$ lymphocytes and relation to hepatic inflammation during chronic HCV infection. J Hepatol 2007; 47: 316-24.

[4] Sakaguchi S, Miyara M, Costantino CM, Hafler DA. FOXP3 ${ }^{+}$regulatory $\mathrm{T}$ cells in the human immune system. Nat Rev Immunol 2010; 10: 490-500.

[5] Belkaid Y, Tarbell K. Regulatory T cells in the control of host-microorganism interactions. Annu Rev Immunol 2009; 27: 551-89.

[6] Losikoff PT, Self AA, Gregory SH. Dendritic cells, regulatory T cells and the pathogenesis of chronic hepatitis C. Virulence 2012; 3: 610-20.

[7] Self AA, Losikoff PT, Gregory SH. Divergent contributions of regulatory $T$ cells to the pathogenesis of chronic hepatitis C. Hum Vaccin Immunother 2013; 9: 1569-76.

[8] Miyara M, Sakaguchi S. Human FoxP3 ${ }^{+} \mathrm{CD}^{+}$regulatory T cells: their knowns and unknowns. Immunol Cell Biol 2011; 89: 346-51.

[9] Jonuleit H, Schmitt E, Kakirman H, Stassen M, Knop J, Enk AH. Infectious tolerance: human $\mathrm{CD}^{+} 5^{+}$regulatory $\mathrm{T}$ cells convey suppressor activity to conventional $\mathrm{CD} 4^{+} \mathrm{T}$ helper cells. J Exp Med 2002; 196: 255-60. 
[10] Gravano DM, Vignali DA. The battle against immunopathology: infectious tolerance mediated by regulatory T cells. Cell Mol Life Sci 2012; 69: 1997-2008.

[11] Li S, Jones KL, Woollard DJ, Dromey J, Paukovics G, Plebanski M, et al. Defining target antigens for $\mathrm{CD}^{2} 5^{+} \mathrm{FoxP}^{+} \mathrm{IFN}-\gamma$ regulatory $\mathrm{T}$ cells in chronic hepatitis $\mathrm{C}$ infection. Immunol Cell Biol 2007; 85: 197-204.

[12] Sayers EW, Barrett T, Benson DA, Bolton E, Bryant SH, Canese K, et al. Database resources of the National Center for Biotechnology Information. Nucleic Acids Res 2012; 40: D13-D25.

[13] Moise L, Gutierrez AH, Bailey-Kellogg C, Terry F, Leng Q, Abdel Hady KM, et al. The twofaced T cell epitope: Examining the host-microbe interface with JanusMatrix. Hum Vaccin Immunother 2013; 9: 1577-86.

[14] He L, De Groot AS, Gutierrez AH, Martin WD, Moise L, Bailey-Kellogg C. Integrated assessment of predicted MHC binding and cross-aonservation with self reveals patterns of viral camouflage. BMC Bioinf 2014; in press.

[15] McNamara BC, Losikoff PT, Huguenin L, Macalino GE, Rich JD, Gregory SH. Increasing hepatitis $\mathrm{C}$ prevalence and associated risk behaviors among incarcerated young adults. $\mathrm{J}$ Urban Health 2013; 91: 376-82.

[16] Rudolph MG, Stanfield RL, Wilson IA. How TCRs bind MHCs, peptides, and coreceptors. Annu Rev Immunol 2006; 24: 419-66.

[17] Mishra S, Losikoff PT, Self AA, Terry F, Ardito MT, Tassone R, et al. Peptide-pulsed dendritic cells induce the hepatitis $C$ viral epitope-specific responses of naïve human $T$ cells. Vaccine 2014; 32: 3285-92.

[18] Southwood S, Sidney J, Kondo A, del Guercio MF, Appella E, Hoffman S, et al. Several common HLA-DR types share largely overlapping peptide binding repertoires. J Immunol 1998; 160: 3363-73. 
[19] Deaglio S, Dwyer KM, Gao W, Friedman D, Usheva A, Erat A, et al. Adenosine generation catalyzed by CD39 and CD73 expressed on regulatory T cells mediates immune suppression. J Exp Med 2007; 204: 1257-65.

[20] Ebinuma H, Nakamoto N, Li Y, Price DA, Gostick E, Levine BL, et al. Identification and in vitro expansion of functional antigen-specific $\mathrm{CD}_{2} 5^{+} \mathrm{FoxP}^{+}$regulatory $\mathrm{T}$ cells in hepatitis $\mathrm{C}$ virus infection. J Virol 2008; 82: 5043-53.

[21] Battaglia A, Buzzonetti A, Monego G, Peri L, Ferrandina G, Fanfani F, et al. Neuropilin-1 expression identifies a subset of regulatory $T$ cells in human lymph nodes that is modulated by preoperative chemoradiation therapy in cervical cancer. Immunology 2008; 123: 129-38.

[22] Yadav M, Louvet C, Davini D, Gardner JM, Martinez-Llordella M, Bailey-Bucktrout S, et al. Neuropilin-1 distinguishes natural and inducible regulatory $\mathrm{T}$ cells among regulatory $\mathrm{T}$ cell subsets in vivo. J Exp Med 2012; 209: 1713-9.

[23] Lechner F, Wong DK, Dunbar PR, Chapman R, Chung RT, Dohrenwend P, et al. Analysis of successful immune responses in persons infected with hepatitis C virus. J Exp Med 2000; 191: 1499-512.

[24] Ulsenheimer A, Gerlach JT, Gruener NH, Jung MC, Schirren CA, Schraut W, et al. Detection of functionally altered hepatitis C virus-specific CD4 T cells in acute and chronic hepatitis C. Hepatology 2003; 37: 1189-98.

[25] Gruener NH, Lechner F, Jung MC, Diepolder H, Gerlach T, Lauer G, et al. Sustained dysfunction of antiviral CD8 ${ }^{+} \mathrm{T}$ lymphocytes after infection with hepatitis C virus. J Virol 2001; 75: 5550-8.

[26] Li S, Floess S, Hamann A, Gaudieri S, Lucas A, Hellard M, et al. Analysis of FOXP3 ${ }^{+}$ regulatory $\mathrm{T}$ cells that display apparent viral antigen specificity during chronic hepatitis $\mathrm{C}$ virus infection. PLoS Pathog 2009; 5: e1000707.

[27] Kanduc D. HCV: Written in our DNA. Self Nonself 2011; 2: 108-13. 
[28] Kusalik A, Bickis M, Lewis C, Li Y, Lucchese G, Marincola FM, et al. Widespread and ample peptide overlapping between HCV and Homo sapiens proteomes. Peptides 2007; 28: 1260-7.

[29] Xing Q, Hu D, Shi F, Chen F. Role of regulatory T cells in patients with acute herpes zoster and relationship to postherpetic neuralgia. Arch Dermatol Res 2013; 305: 715-22.

[30] Aandahl EM, Michaelsson J, Moretto WJ, Hecht FM, Nixon DF. Human CD4+CD25 regulatory $\mathrm{T}$ cells control $\mathrm{T}$-cell responses to human immunodeficiency virus and cytomegalovirus antigens. J Virol 2004; 78: 2454-9.

[31] Tran DQ, Ramsey H, Shevach EM. Induction of FOXP3 expression in naive human CD4 ${ }^{+}$OXP3 $\mathrm{T}$ cells by $\mathrm{T}$-cell receptor stimulation is transforming growth factor-beta dependent but does not confer a regulatory phenotype. Blood 2007; 110: 2983-90.

[32] Jana S, Campbell H, Woodliff J, Waukau J, Jailwala P, Ghorai J, et al. The type of responder T-cell has a significant impact in a human in vitro suppression assay. PLoS ONE 2010; 5: e15154.

[33] Taylor AL, Llewelyn MJ. Superantigen-induced proliferation of human $\mathrm{CD}^{+} \mathrm{CD} 25^{-} \mathrm{T}$ cells is followed by a switch to a functional regulatory phenotype. J Immunol 2010; 185: 6591-8.

[34] Shevach EM, DiPaolo RA, Andersson J, Zhao DM, Stephens GL, Thornton AM. The lifestyle of naturally occurring $\mathrm{CD} 4^{+} \mathrm{CD} 25^{+} \mathrm{Foxp}^{+}$regulatory T cells. Immunol Rev 2006; 212: 60-73.

[35] Sakai A, Claire MS, Faulk K, Govindarajan S, Emerson SU, Purcell RH, et al. The p7 polypeptide of hepatitis C virus is critical for infectivity and contains functionally important genotype-specific sequences. Proc Natl Acad Sci U S A 2003; 100: 11646-51.

[36] Kim Y, Vaughan K, Greenbaum J, Peters B, Law M, Sette A. A meta-analysis of the existing knowledge of immunoreactivity against hepatitis C virus (HCV). PLoS ONE 2012; 7: e38028.

[37] Della BS, Crosignani A, Riva A, Presicce P, Benetti A, Longhi R, et al. Decrease and dysfunction of dendritic cells correlate with impaired hepatitis C virus-specific CD4 ${ }^{+} \mathrm{T}$-cell proliferation in patients with hepatitis C virus infection. Immunology 2007; 121: 283-92. 
[38] Ayers CL, Firan M, Pillai V, Lee WM, Karandikar NJ. Viral interactions with B-cells contribute to increased regulatory T-cells during chronic HCV infection. Viral Immunol 2011; 24: 119-29.

[39] Thornton AM, Korty PE, Tran DQ, Wohlfert EA, Murray PE, Belkaid Y, et al. Expression of Helios, an Ikaros transcription factor family member, differentiates thymic-derived from peripherally induced Foxp3 ${ }^{+}$T regulatory cells. J Immunol 2010; 184: 3433-41. 
Table I. Human Subjects

\begin{tabular}{|c|c|c|c|c|c|c|}
\hline Subject ID\# & Age & HCV Status & Viral Load IU/ml & Genotype & Antibody & HLA-DRB1 \\
\hline 229 & 28 & Infected & 170,620 & 1 & + & 03,11 \\
\hline 236 & 29 & Infected & 602,611 & 1 & + & 01,11 \\
\hline 260 & 28 & Infected & $1,410,524$ & 3 & + & 03,07 \\
\hline 261 & 25 & Infected & $7,464,611$ & 1 & + & 01,11 \\
\hline 265 & 22 & Infected & $21,917,190$ & $1 \mathrm{a}$ & + & 13,15 \\
\hline 272 & 23 & Infected & 458 & $1 a$ & + & 03,11 \\
\hline 279 & 25 & Infected & $1,788,326$ & $1 \mathrm{a}$ & + & 13,15 \\
\hline 282 & 28 & Infected & 86,678 & $1 \mathrm{a}$ & + & 03,04 \\
\hline 216 & 23 & Clearer & NA & NA & + & 07:01 \\
\hline 221 & 27 & Clearer & & & + & 03,11 \\
\hline 222 & 25 & Clearer & & & + & 03,15 \\
\hline 246 & 26 & Clearer & & & + & 01,04 \\
\hline 267 & 23 & Clearer & & & + & 03,11 \\
\hline 264 & 27 & Clearer & & & + & 03,11 \\
\hline 248 & 26 & Non-infected & & & - & 04,11 \\
\hline 259 & 26 & Non-infected & & & - & 04,11 \\
\hline 262 & 22 & Non-infected & & & - & 03,11 \\
\hline 257 & 22 & Non-infected & & & - & 03,15 \\
\hline 263 & 26 & Non-infected & & $\downarrow$ & - & 01,03 \\
\hline
\end{tabular}

$\mathrm{NA}=$ not applicable/available . 
Table II. JanusMatrix Analysis

\begin{tabular}{lccc}
\hline Description & ICS & $\begin{array}{c}\text { \# Cross-reactive } \\
\text { Epitopes per ICS }\end{array}$ & $\begin{array}{c}\text { \# Human Proteins } \\
\text { containing Cross- } \\
\text { reactive Epitopes }\end{array}$ \\
\hline HCV_G1_p7_794 & WPLLLLLLALPQRAYAQ & 5.0 & 264 \\
Human p7_794 & PLLLLLLSLPPRA & 4.0 & 325 \\
HCV_G1_NS4b_1941 & AARVTQILSSLTITQLLKRLHQWI & 6.0 & 28 \\
\hline
\end{tabular}

${ }^{a}$ Human homolog; highly conserved sequence derived from hepatitis $C$ virus, genotype 1 .

${ }^{\mathrm{b}}$ Analog; sequence found in multiple human proteins.

${ }^{c}$ Validated promiscuous, $T_{\text {eff }}$ cell ICS derived from hepatitis $C$ virus, genotype 1 [17]. 


\section{Figure Legends}

Fig. 1. HCV_G1_p7_794 induces the production of $\mathrm{CD}^{+} \mathrm{CD}^{+}{ }^{+} \mathrm{FoxP3}{ }^{+}$cells in cultures of PBMCs derived from HCV-infected patients. PBMCs were cultured in the presence of medium alone, $10 \mu \mathrm{g} / \mathrm{ml}$ HCV_G1_p7_794 or $10 \mu \mathrm{g} / \mathrm{ml}$ HCV_G1_NS4b_1941. Cells collected after 5 days incubation were analyzed by flow cytometry $(A)$. The $C D 3^{+} C D 4^{+} F o x P 3^{+}$cells were further characterized by the expression of CD25 and CD39 where the dotted line represents the isotype control (B). The gating scheme and representative analyses are shown.

Fig. 2. HCV_G1_p7_794 fails to elicit an increase in $\mathrm{CD}^{+} \mathrm{CD} 4^{+}$FoxP3 ${ }^{+}$cells among PBMCs derived from non-infected individuals. PBMCs obtained from infected patients $\left(\mathrm{Ab}^{+} \mathrm{VL}^{+}, \mathrm{n}=4\right)$, patients who clear infection $\left(A b^{+} V^{-}, n=6\right)$ and non-infected controls $\left(A b^{-} V^{-}, n=4\right)$ were cultured with medium alone, HCV_G1_p7_794 or HCV_G1_NS4b_1941 (A). The cells collected after 5 days were analyzed by flow cytometry. ${ }^{\star}$ Significantly different: ${ }^{\star} P=0.014 ;{ }^{* \star} P<0.001$.

PBMCs obtained from $\mathrm{Ab}^{+} \mathrm{VL}^{+}$patients $(n=4)$ and $\mathrm{Ab}^{-} \mathrm{VL}^{-}$controls $(n=4)$ were cultured in the presence or absence of the human p7_794 analog (B). Significantly more $\mathrm{CD} 3^{+} \mathrm{CD} 4^{+} \mathrm{FoxP} 3^{+}$cells were recovered from PBMC cultured with the analog than medium alone: ${ }^{\star} P=0.001 ;{ }^{* \star} P=0.048$.

Fig. 3. HCV_G1_p7_794 suppresses the proliferation of PBMCs derived from HCV-infected patients. CSFE-labeled, $\mathrm{Ab}^{+} \mathrm{VL}^{+}$PBMCs were cultured with medium alone, or medium containing anti-CD3, HCV_G1_p7_794, or anti-CD3 and HCV_G1_p7_794. Cells were collected after 5 days; proliferation was estimated by flow cytometry and a loss in fluorescence intensity. Data were obtained in a single experiment representative of two HCV-infected patients (A). PBMCs obtained from the three patients listed were cultured 5 days in the presence of anti-CD3 or $20 \mathrm{ng} / \mathrm{ml} \mathrm{IL}-2$ with or without HCV_G1_p7_794; cell proliferation was estimated by $\left[{ }^{3} \mathrm{H}\right.$-thymidine incorporated during the last 18 hours of incubation (B). 
Fig. 4. Fewer HCV-G1_p7_794-responsive $T_{\text {reg }}$ cells express CD304 (neuropilin). PBMCs obtained from an infected patient (representative of 4 patients) were incubated in medium alone $(A)$ or medium that contained HCV_G1_p7_794 (B). The cells were collected on day 5, stained and analyzed by flow. Panels on the right indicate the percentage of $\mathrm{CD} 4^{+} \mathrm{FoxP} 3^{+}$cells in each population that expresses CD304. 
Losikoff et al.

Figure 1

A.

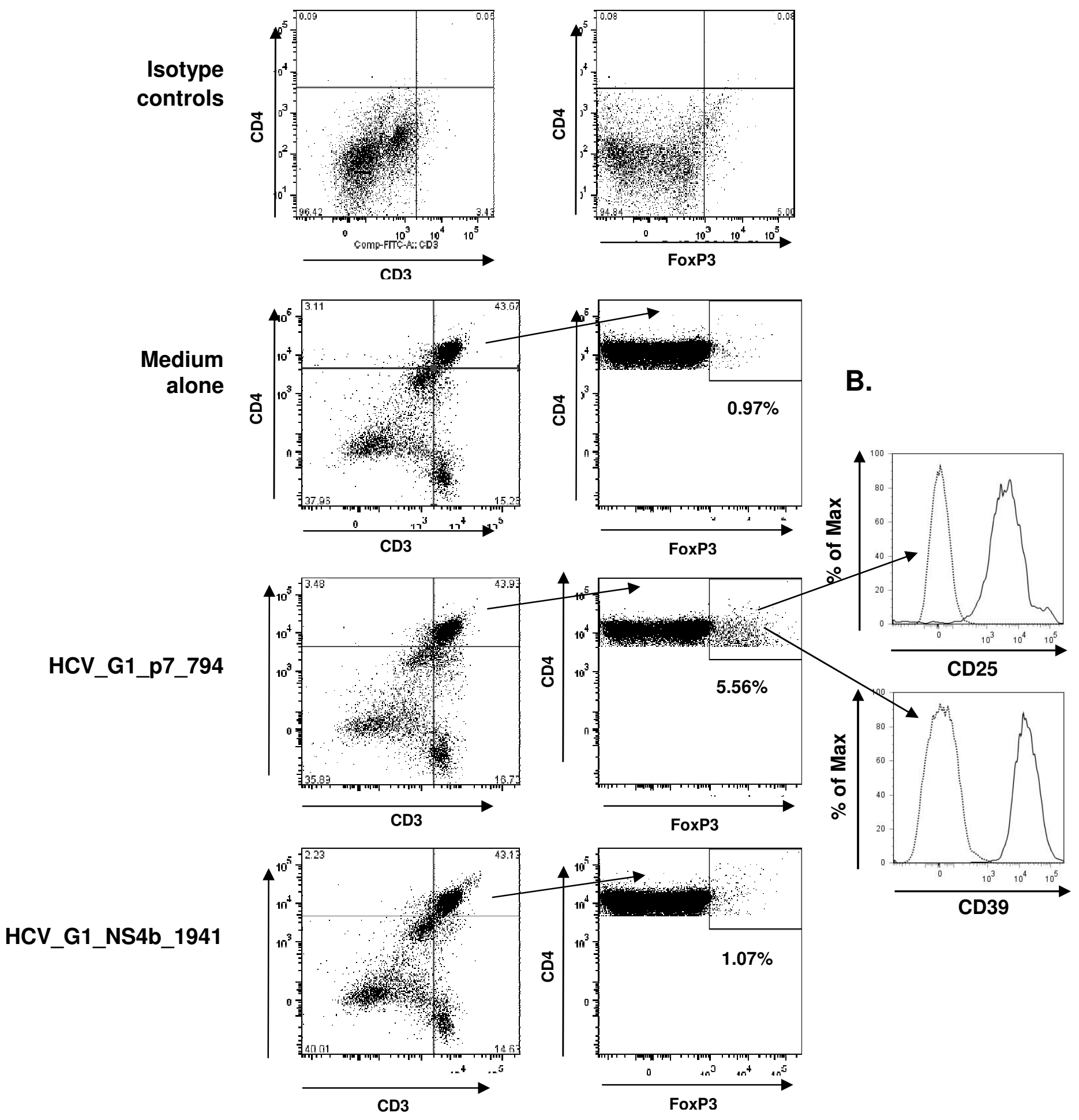


A.
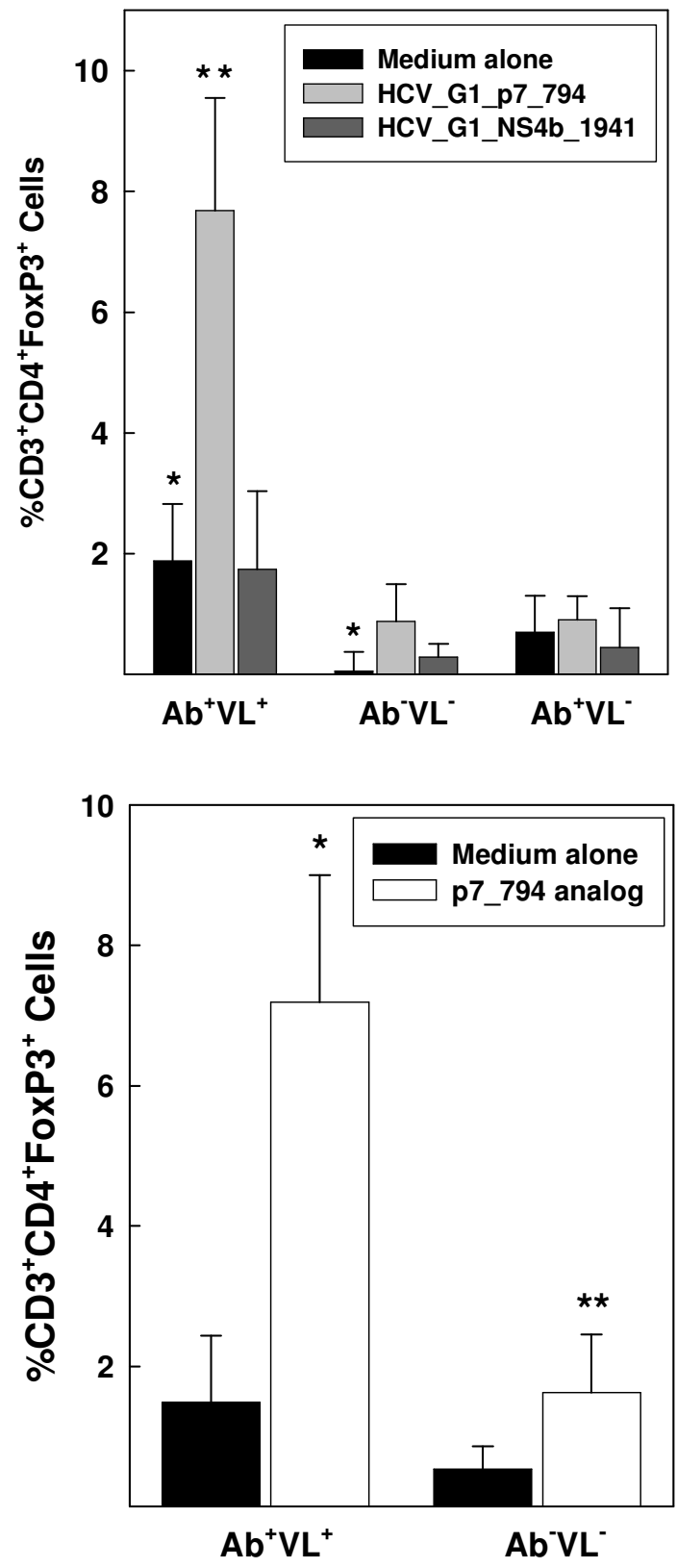
Losikoff et al.

Figure 3
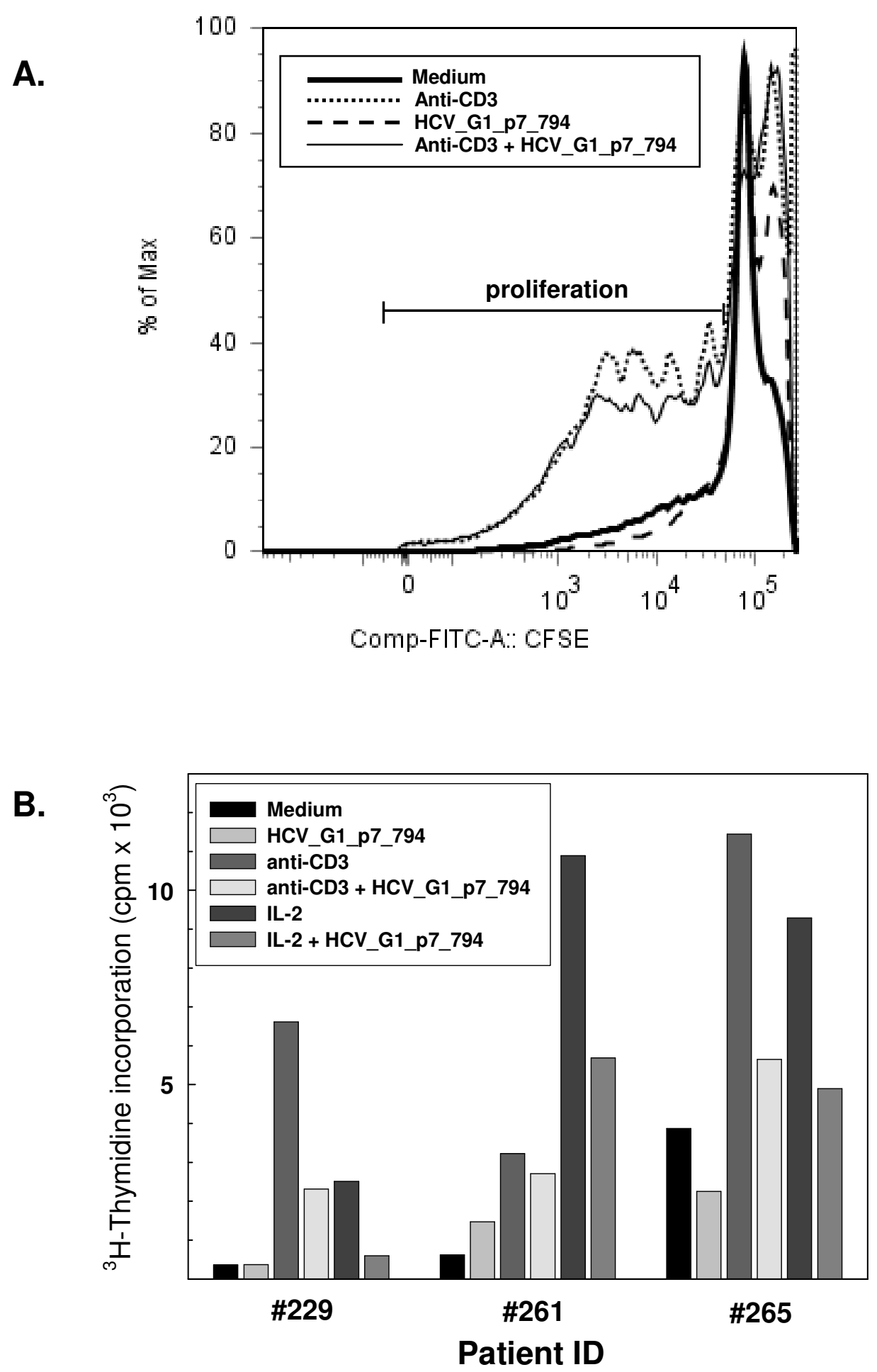
Losikoff et al.

Figure 4

A.

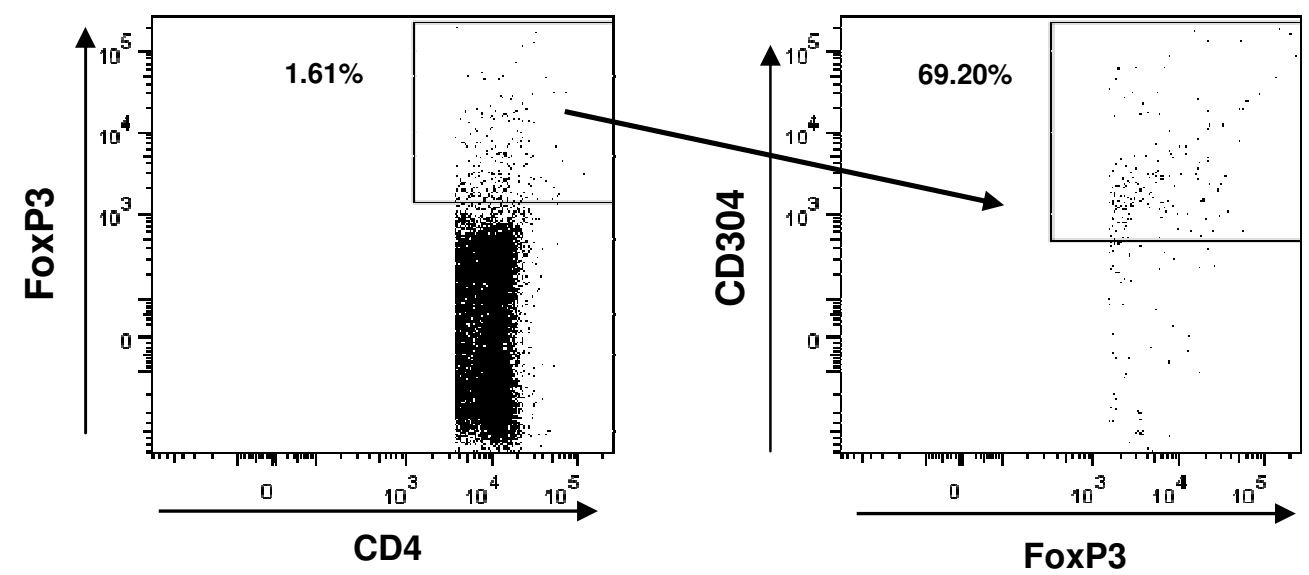

B.






\title{
Supplementary Materials
}

\section{HCV Epitope, Homologous to Multiple Human Protein Sequences, Induces a Regulatory T Cell Response in Infected Patients}

\author{
Phyllis T. Losikoff, ${ }^{1}$ Sasmita Mishra, ${ }^{1}$ Frances Terry, ${ }^{2}$ Andres Gutierrez, ${ }^{3}$ Matt T. Ardito, ${ }^{2}$ \\ Loren Fast ${ }^{1,3}$ Martha Nevola, ${ }^{1}$ William D. Martin, ${ }^{2}$ \\ Chris Bailey-Kellogg, ${ }^{4}$ Anne S. De Groot ${ }^{2,3}$ and Stephen H. Gregory ${ }^{1}$
}

\section{Table of Contents}

Materials and Methods:

HLA-DRB1-restricted epitope selection: page 2

Peripheral blood mononuclear cell (PBMC) cultures: page 2

Flow cytometry: page 3

Statistical Analysis: page 3

Figures

Supplementary Fig. 1: page 4

Supplementary Fig. 2: page 5

Supplementary Fig. 3: page 6

Table I: page 7

References: page 8 


\section{Materials and Methods}

\section{HLA-DRB1-restricted epitope selection}

HCV sequences were acquired from the Los Alamos database [1,2]. Nine-mer amino acid sequences, capable of fitting the binding groove of HLA class II molecules and highly conserved across HCV genotype $1 \mathrm{a}$ and $1 \mathrm{~b}$ isolates, were identified and scored for potential to bind eight common HLA class II (DRB1) alleles using bioinformatics tools [3-5]. HLA class II immunogenic consensus sequences (ICS) were identified and constructed by assembling potentially immunogenic 9-mers into 18-25 amino acid sequence [3]. ICS construction improves the probability that an epitope will be presented in the context of more than one HLA allele, thus broadening the response of an HLA-diverse human population. Twenty ICS derived from HCV genotypes $1 \mathrm{a}$ and $1 \mathrm{~b}$ were synthesized as peptides using 9-fluoronylmethoxycarbonyl chemistry and purified $>85 \%$ by 21 st Century Biochemicals (Marlboro, MA). Each of these "promiscuous" ICS contained between 5 and 28 predicted HLA binding motifs, and were bound by multiple HLA-DRB1 alleles in competitive binding assays as described previously [6,7]. Each ICS was also evaluated for human homology (>7 shared identities per 9-mer frame) using GenBank BLAST [8].

\section{Peripheral blood mononuclear cell (PBMC) cultures}

Cryopreserved PBMCs from participating subjects were thawed; suspended in HEPES-buffered RPMI1640 medium supplemented with 10\% HuAB serum (Valley Biomedical, Winchester, VA), glutamine, $100 \mathrm{U} / \mathrm{ml}$ penicillin and $100 \mu \mathrm{g} / \mathrm{ml}$ streptomycin; and rested overnight at $37^{\circ} \mathrm{C}$ in a humidified, $\mathrm{CO}_{2}$ incubator. On the following day, the PBMCs were centrifuged and resuspended in fresh medium containing $5 \%$ HuAB serum; $1 \times 10^{6} \mathrm{cells} / \mathrm{ml}$ were transferred to deep, flat-bottom, nontreated 48-well plates. The peptide sequence indicated in the text was added $(10 \mu \mathrm{g} / \mathrm{ml}$ final concentration) and the cells were incubated for 5 days. PBMCs cultured in the presence of medium 
with $0.1 \%$ DMSO served as a negative control. Half the spent medium was replaced on day 3 . The cells were collected for analysis on day 5 .

For proliferation assays, cells rested overnight were labeled with carboxyfluorescein diacetate, succinimidyl ester (CFSE: Life Technologies Corporation, Carlsbad, CA) prior to culture in the presence or absence of $10 \mu \mathrm{g} / \mathrm{ml}$ HCV_G1_p7_794,10 $\mu \mathrm{g} / \mathrm{ml}$ human p7_794 or $30 \mathrm{ng} / \mathrm{ml}$ anti-CD3 monoclonal antibody (clone HIT3a; BioLegend, San Diego, CA). Cell proliferation was evaluated by flow cytometric analysis according to the protocol provided by Life Technologies in which a loss in fluorescence intensity correlates directly with the extent of replication. Alternatively, non-CSFElabeled cells were pulsed with $0.1 \mu \mathrm{Ci}\left[{ }^{3} \mathrm{H}\right]$-thymidine during the last 18 hours of the 5 -day culture period; radiolabeled-thymidine incorporation was quantified by liquid scintillation counting.

\section{Flow cytometry}

Stimulated PBMC were quantified and characterized in accordance with methods we described previously [9]. The following dye-conjugated mouse monoclonal antibodies were purchased from BioLegend (San Diego, CA) and used: CD3, CD4 (clone OKT4), CD8a (clone HIT8a); CD39 (clone A1), and CD304 (clone 14H4); anti-human CD25 (clone M-A251) and anti-human FoxP3 (clone 236a) were purchased from BD Biosciences (San Jose, CA). Data were collected on a BD LSRII Flow Cytometer (BD Biosciences, San Jose, California) and analyzed using FlowJo software (Tree Star, Inc., Ashland, OR). All analyses were conducted using the appropriate isotype controls to correct for non-specific staining.

\section{Statistical Analysis}

The results were analyzed using the SigmaStat statistics program (Aspire Software International). Means were compared using a non-paired Student's $t$ test or a Mann-Whitney Rank Sum test. Aggregate data were compared by one-way analysis of variance; the Dunnett's test determined which groups differed significantly. 


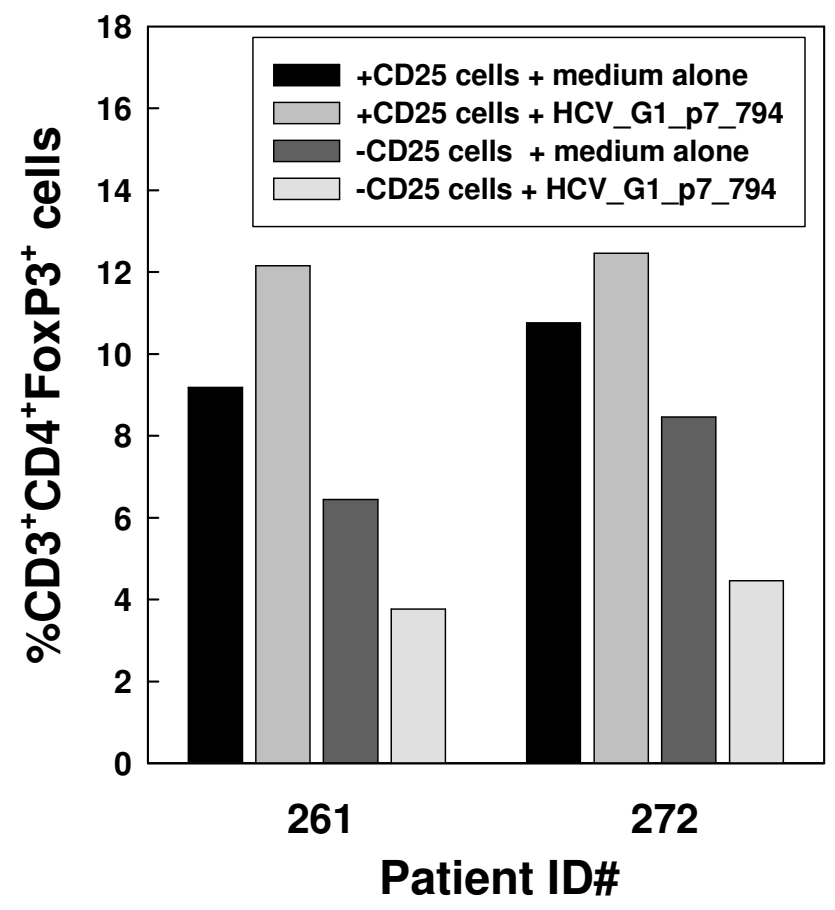

Supplementary Fig. 1. CD25 ${ }^{+}$cell depletion prior to culture abrogates the $\mathrm{T}_{\text {reg }}$ cell response to HCV_G1_p7_794.

PBMCs obtained from the two HCV-infected patients indicated were either depleted or not depleted of CD25 expressing cells using antibody-coated magnetic beads (Miltenyi Biotech, Auburn, CA). Depleted (CD25) and non-depleted (CD25 $\left.{ }^{+}\right)$PBMCs were cultured in the presence or absence of medium that contained $10 \mu \mathrm{g} / \mathrm{ml}$ HCV_G1_p7_794. The cells were collected after 5 days incubation and the $\mathrm{CD} 3^{+} \mathrm{CD} 4^{+} \mathrm{FoxP}^{+} \mathrm{T}$ cells were quantified by flow cytometry. 




Supplementary Fig. 2. HCV_G1_p7_794, derived from HCV genotype 1, induces the production of $\mathrm{CD}^{+} \mathrm{CD}^{+}{ }^{+} \mathrm{FoxP} 3^{+}$cells in cultures of PBMCs obtained from an HCV genotype 3 infected patient. PBMCs were cultured in the presence of medium alone, HCV_G1_p7_794, HCV_G1_NS4b_1941 or human p7_794 analog. Cells collected after 5 days incubation were analyzed by flow cytometry. 


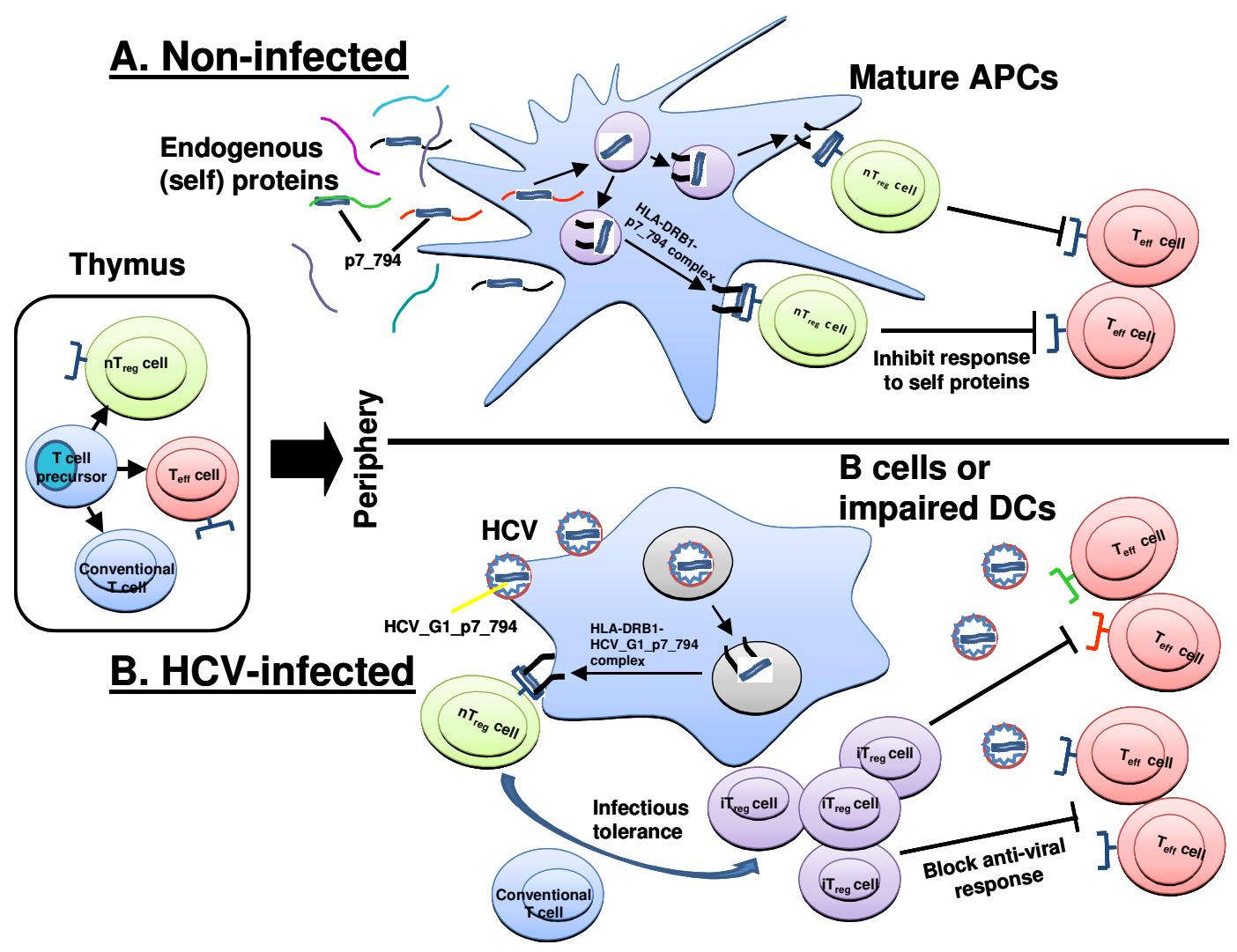

Supplementary Fig. 3. Schematic: HCV_G1_p7_794 presentation by B cells or impaired DCs promotes infectious tolerance, loss of anti-viral $\mathrm{T}_{\text {eff }}$ cell activity and persistent $\mathrm{HCV}$ infection. During the normal course of protein turnover, mature antigen presenting cells (APCs) process and present the p7_794 sequence in hundreds of distinct self-proteins. Immune recognition and the activity of p7 794-specific $\mathrm{CD}^{+} \mathrm{CD}^{+} \mathrm{FoxP}^{+} \mathrm{CD} 304^{+} \mathrm{nT}_{\text {reg }}$ cells suppress the autoimmune response of $T_{\text {eff }}$ cells specific for the same self-proteins (A). In HCV-infected patients, HCV_G1_p7_794 presented by $B$ cells or impaired (phenotypically immature) DCs induces the epitope-specific response of $\mathrm{nT}_{\text {reg }}$ cells and the subsequent conversion of conventional $\left(\mathrm{CD}^{+} \mathrm{CD}^{+}{ }^{+} \mathrm{FoxP} 3^{-}\right) \mathrm{T}^{-}$cells to 
$\mathrm{CD}^{+} \mathrm{CD}^{+}{ }^{+} \mathrm{FoxP}^{+} \mathrm{CD} 304^{+} \mathrm{iT}_{\text {reg }}$ cells. $\mathrm{iT}_{\text {reg }}$ cells, in turn, block the anti-viral response of $\mathrm{T}_{\text {eff }}$ cells specific for HCV_G1_p7_794, as well as other viral epitopes (bystander suppression) (B). 
Table I. HCV_G1_p7_794 induces $\mathrm{CD}^{+} \mathrm{CD}^{+} \mathrm{FoxP3}^{+}$cells in co-cultures composed of purified, naïve human $T$ cells and $B$ cells

\begin{tabular}{lrcc}
\hline & 0.1\% DMSO & HCV_G1_p7_794 & HCV_G1_NS4b_1941 \\
\hline FoxP3 $^{\text {+a }}$ & 2.12 & 7.76 & 2.23 \\
CD39 $^{+b}$ & 94.65 & 99.00 & 96.09 \\
CD152 $^{+b}$ & 0.63 & 0.55 & 1.29 \\
CD304 $^{+b}$ & 61.01 & 37.99 & 61.49 \\
HELIOS $^{+\mathbf{b}}$ & 3.16 & 1.61 & 4.78 \\
\hline
\end{tabular}

CD19 ${ }^{+} \mathrm{B}$ cells and pan-T cells were purified from the PBMCs of a normal blood donor using magnetic beads (Miltenyi Biotec). Equal numbers were suspended in X-VIVO 15 medium (Lonza, Walkerville, MD) supplemented with glutamine, penicillin, streptomycin, and $50 \mathrm{U} / \mathrm{ml}$ recombinant human IL-2 (Roche Applied Science, Indianapolis, IN) and subsequently co-cultured in the presence of $0.1 \%$ DMSO, $10 \mu \mathrm{g} / \mathrm{ml}$ HCV_G1_p7_794 or $10 \mu \mathrm{g} / \mathrm{ml}$ HCV_G1_NS4b_1941. The cells were collected after 14 days incubation and the $\mathrm{CD}^{+}$cells were phenotyped by flow cytometry. Data are the results of a single experiment representative of two identical experiments.

aPercentage of $\mathrm{CD} 3^{+} \mathrm{CD} 4^{+}$cells.

${ }^{\mathrm{b} P e r c e n t a g e}$ of FoxP3 ${ }^{+}$cells. 


\section{References}

[1] Kuiken C, Yusim K, Boykin L, Richardson R. The Los Alamos hepatitis C sequence database. Bioinformatics 2005; 21: 379-84.

[2] Yusim K, Richardson R, Tao N, Dalwani A, Agrawal A, Szinger J, et al. Los Alamos hepatitis C immunology database. Appl Bioinformatics 2005; 4: 217-25.

[3] De Groot AS, Bishop EA, Khan B, Lally M, Marcon L, Franco J, et al. Engineering immunogenic consensus T helper epitopes for a cross-clade HIV vaccine. Methods 2004; 34 : 476-87.

[4] De Groot AS, Jesdale BM, Szu E, Schafer JR, Chicz RM, Deocampo G. An interactive Web site providing major histocompatibility ligand predictions: application to HIV research. AIDS Res Hum Retroviruses 1997; 13: 529-31.

[5] De Groot AS, Martin W. Reducing risk, improving outcomes: bioengineering less immunogenic protein therapeutics. Clin Immunol 2009; 131: 189-201.

[6] Mishra S, Losikoff PT, Self AA, Terry F, Ardito MT, Tassone R, et al. Peptide-pulsed dendritic cells induce the hepatitis $C$ viral epitope-specific responses of naïve human $T$ cells. Vaccine 2014; 32: 3285-92.

[7] Ardito M, Fueyo J, Tassone R, Terry F, DaSilva K, Zhang S, et al. An integrated genomic and immunoinformatic approach to $H$. pylori vaccine design. Immunome Res 2011; 7: 1 .

[8] Sayers EW, Barrett T, Benson DA, Bolton E, Bryant SH, Canese K, et al. Database resources of the National Center for Biotechnology Information. Nucleic Acids Res 2012; 40: D13-D25.

[9] Duwaerts CC, Gehring S, Cheng CW, van Rooijen N, Gregory SH. Contrasting responses of Kupffer cells and inflammatory mononuclear phagocytes to biliary obstruction in a mouse model of cholestatic liver injury. Liver Int 2013; 33: 255-65. 